\author{
Marquette University \\ e-Publications@Marquette
}

Social and Cultural Sciences Faculty Research and Publications

$7-2015$

\title{
Ethnographic Refusal as Research Method: Example from a Study of a Family Court Child Custody Mediation Program
}

Alexandra Crampton

Marquette University, alexandra.crampton@marquette.edu

Follow this and additional works at: https://epublications.marquette.edu/socs_fac

Part of the Social and Behavioral Sciences Commons

\section{Recommended Citation}

Crampton, Alexandra, "Ethnographic Refusal as Research Method: Example from a Study of a Family Court Child Custody Mediation Program" (2015). Social and Cultural Sciences Faculty Research and Publications. 87.

https://epublications.marquette.edu/socs_fac/87 
Marquette University

e-Publications@Marquette

\title{
Social and Cultural Sciences Faculty Research and Publications/College of Arts and Sciences
}

This paper is NOT THE PUBLISHED VERSION; but the author's final, peer-reviewed manuscript. The published version may be accessed by following the link in the citation below.

Qualitative Social Work, Vol. 14, No. 4 (July 1, 2015): 453-470. DOI. This article is C SAGE Publications and permission has been granted for this version to appear in e-Publications@Marquette. SAGE Publications does not grant permission for this article to be further copied/distributed or hosted elsewhere without the express permission from SAGE Publications.

\section{Ethnographic Refusal as Research Method: Example from A Study of a Family Court Child Custody Mediation Program}

\author{
Alexandra Crampton \\ Department of Social and Cultural Sciences, Marquette University, Milwaukee, WI
}

\begin{abstract}
Mediation is a dispute resolution process in which a third party neutral facilitates discussion towards amicable agreement. Parents in Wisconsin filing disputed claims in family court over child custody or physical residence must attend mediation before going back to court. I began research on the Milwaukee Family Court Child Custody Mediation program three years ago with anticipation of data collection challenges due to sensitivity of the topic and need for multiple research permissions. Multiple and ongoing permission is necessary given an ethnographic extended case study research design. This approach was chosen to analyze the meanings of mediation within larger social contexts of court process and private family lives. While refusal from potential research subjects was understandable, I did not anticipate my difficulty staying with the research both in data
\end{abstract}


collection and initial analysis. This essay explains my dilemma as an example of what anthropologist Sherry Ortner calls "ethnographic refusal," which is also an occupational hazard of using direct engagement to understand lived experience. First, I explain how refusal can become part of ethnographic fieldwork and then use my study as an example. I focus on describing how emotional intensity within the research sites brought refusal that was eventually addressed as a productive rather than obstructive part of the research process. While it is important to avoid risk in going too far in trying to fully engage with others, there is also risk in not going far enough to engage with the full humanity of people struggling in difficult contexts.

\section{Keywords}

Ethnography, fieldwork, family, emotions, reflexivity, law

\section{Introduction}

When I began research on the Milwaukee Family Court Child Custody Mediation program three years ago, I anticipated difficulty in data collection due to the sensitivity of the topic and need for multiple research permissions. Mediation is a dispute resolution process in which a third party neutral (the mediator) facilitates discussion with an ideal outcome of amicable agreement for "disputants." Family court in Wisconsin, as in most US states, mandates that parents who file disputed claims over legal decision making or physical residence of children must attend mediation before continuing in the court process (Applegate and Beck, 2013). Researching the mediation process requires research site permission from the court and mediators (who typically use private offices), and obtaining consent from the court, mediators, parents, and possibly lawyers. In addition, an ethnographic component was added to an extended case study design, which necessitates ongoing consent by all parties for data collection on mediation cases as part of court process and within private lives of parents and family. To my surprise, research refusal over time became rare, particularly as I became more comfortable in research settings of court and mediation sessions as an observer, and I became a familiar face to others. The problem I explore in this essay is not refusal by research participants but rather refusal from me as a researcher. Ethnographic methods necessitate getting "into" the lived experience of others as much as possible, and I continually found myself resisting this while in the field and in writing up notes afterwards. In trying to stay with the research both literally in terms of showing up to collect data and in engaged data analysis, the

anthropologist Sherry Ortner's term, "ethnographic refusal" (1995) has been useful. By naming this stuckness as ethnographic refusal rather than as research failure, my inner refusal has become a means both to refine my stance as an ethnographer and to identify local refusal as part of the larger social context. The purpose of this essay is to explain how ethnographic refusal may become part of research and how it can be become a productive part of research data as part of the ethnographic process. I first introduce ethnographic refusal as among challenges of using direct engagement to learn the lived experience of others. More detail follows on ethnographic methods in developing an ethnographic stance and potential refusal. I then use my current study as an example of how refusal emerged in research on a sensitive subject, and how refusal became a productive rather than obstructive part of this research.

\section{Challenges of direct practice in research and social work}

Ethnographic research is similar to social work practice in that emphasis is placed on learning through direct engagement and understanding how local context impacts behavior and subjective meaning (Floersch et al., 2014). Using anthropological terms, ethnographic researchers integrate professional training and scholarship with the direct experience of full immersion within a social context in order to develop an outsider "etic" analysis that authentically integrates insider "emic" perspectives (Bernard, 2002; Fetterman, 2009). This is epistemologically similar to the Person-in-Environment approach of practitioners engaging with client experience and drawing from professional knowledge in order to best identify how to assess and intervene. The 
methods of how to help others and/or help understand others include means of "going there" to where the client "is." Going there requires ability to develop rapport, engage in honest and open communication, and be open to painful and positive experiences (Padgett, 1998). In ethnographic field-based research, this also means literally going to where the social experience under study takes place using the self as the research instrument. The main research method, participant observation, includes,

a standard technique to try to subject yourself, hopefully, to their life circumstances, (which) means that, although, in fact, you can leave at any time, you act as if you can't and you try to accept all the desirable and undesirable things that are a feature of their life (Goffman, 1988: 125).

Given this very personal approach, there are special concerns of ethics and epistemology in working on sensitive topics with vulnerable populations, which social work practitioners may find familiar (Haight et al., 2014). One is failure to truly understand another and instead imposing professional or personal ontologies and assessments (Floersch et al., 2013). Another can be going too far; one can be a risk to others by delving too deeply into personal and potentially damaging (or damning) information (e.g. Mosse, 2005, 2011). Researchers can also be at risk for adapting too easily and becoming an insider who "goes native" or becomes "co-opted" rather than maintaining an ability to maintain appropriate professional distance (Gold in Börjesson, 2014: 409). A third problem in going too far is over personalizing or being overly impacted personally through the research experience as a "vulnerable observer," (Behar, 1996). Professional standards and institutional review board (IRB) review boards provide general guidance on minimizing risk to others through informed consent and opportunity for refusal. Social work practice standards and education teach social workers how to engage effectively within professional boundaries. Researchers address risk and reward of intimate research engagements through scholarship on fieldwork and other qualitative methods (e.g. Pearson and Bourgois, 1995; Wesch, 2007).

This essay contributes to such literature on ethnographic research dilemmas by examining what may be the flipside to the concern of going too far; in my current research project, I have continually encountered what Sherry Ortner refers to as "ethnographic refusal" (Ortner, 1995) which is essentially the problem of getting there (to where the client is) and yet not going far enough. In these cases, it is the ethnographer who refuses engagement without justifiable ethical or epistemological concerns. Ortner identifies in this a "failure of nerve" (p. 190) that results in incomplete description at best and a distorted hiding at worst. How this failure of nerve might emerge during research is next explored through describing ethnographic methods and refusal in more detail.

\section{Ethnographic methods}

\section{Going there}

"Going there" in order to truly understand others was originally characterized (and caricatured) in anthropological fieldwork by the physical immersion and isolation of the researcher. The "lone ethnographer" (Rosaldo, 1993: 31) traveled to a remote village for at least a year to fully absorb social phenomena. Moving into the late 20th century, however, many of these studies were criticized for researcher bias from not going deep enough into empathic understanding and projecting the researcher's culturally inscribed ontologies and epistemologies rather than truly learning emic perspectives (Clifford and Marcus, 1986). Local "natives" were treated as "informants" of their experience rather than active agents in their own lives (and in shaping research). Current methodology entails reflexive engagement and ongoing reflection about how the researcher's personal experience and professional training impact participant observation dynamics and therefore data collection (Davies, 1999; Padgett, 1998). Ethnographers also engage research participants as "interlocutors" rather than passive informants, which includes inviting reactions to the ethnographer's task of understanding by asking questions and testing assumptions for potential emergent hypotheses (Schensul and 
LeCompte, 2013). This is also called "checking in" (Duneier, 1999) and "member checking" (Padgett, 1998). In anthropology, "key informants" are insiders who are more frequently consulted for insider knowledge and as a reality check on ethnographer interpretation (Bernard, 2002). Semi-structured interviews can add more depth than spontaneous field based conversation allows. Data are recorded through collecting local artifacts and documents used in local practice (such as court records), examining personal reactions in journals, documenting events in field notes, and writing up analytic memos to identify emergent hypotheses (Flick, 2014). Multiple data sources collected and analyzed over time improve reliability and "prolonged contact (helps) to minimize reactivity" (Iversen and Armstrong, 2007).

Over time, each researcher develops what Sherry Ortner describes as an "ethnographic stance," in data collection and analysis that is not only a "bodily process in space and time" of field site immersion but also "an intellectual (and moral) positionality, a constructive and interpretive mode" (Ortner, 1995: 173). Ethnographers strive not to remove the self from research in order to be objective but rather to address the subjective dynamics of data collection by the researcher-self as part of data collection and analysis (Davies, 1999; Fetterman, 2009). The accuracy of one's etic analysis comes in part from honestly and authentically integrating the emic because you were engaged in dialogue with interlocutors during and after data collection, and also subjected to the contexts and social realities salient to understanding local experience. In order to not simply impose an outsider's worldview and presumptions, it is important to allow initial research questions and planned data collection to dissolve in the face of questions that emerge through immersion in the field (Fetterman, 2009). This method is time intensive; asking questions many times with many participants in different ways so that patterns of behavior, interaction, and meaning can be identified until additional data no longer adds significantly new information but rather reinforces what the ethnographer has already learned. Over time, research analysis broadens from examining direct field experience to expanding levels of analysis. Michael Burawoy refers to this as the "three dialogues" of reflexive research: the first dialogue is between observers and interlocutors, the second, "between local processes and extralocal forces," and the third of theory (Burawoy, 1998: 5). Researchers may later test published results by sharing with research participants in "valedictory revisits" (Burawoy, 2003: 672).

\section{Ethnographic refusal: A problem of thinning}

Ethnographic research results in a density of data from field notes, analytic memos, journal entries, interviews, recordings, and documents or other artifacts from the field. The ethnographies are evaluated by "thickness" (Geertz, 1973) of description. Ethnographic refusal, then, lies in "thinning" (Ortner, 1995: 180). In her essay, "Resistance and the Problem of Ethnographic Refusal," Ortner critiques ethnographic description in studies of resistance by marginalized and oppressed populations. The failure of nerve she identifies in the ethnographic stance of authors is a refusal to engage with cultural dynamics and intragroup politics that would offer a more complex understanding of resistance than what she views as "romanticism" (p. 177) and "politically sanitized" (p. 176) representations of how people resist domination. Instead, the full humanity and subjectivity of those who are oppressed is lost in the construction of innocent victims (although she uses the term "dissolving subject" (p. 183). She indirectly offers an explanation for this thinning as a fear that this information could be used to rationalize or legitimize domination. Her example is of how exploration of Mayan culturally mediated responses to colonial encounters could be misconstrued as blaming the victim such that the Mayans had it coming to them (p. 178).

In my research, ethnographic refusal arrived much earlier than the write up stage and has been an integral part of the research process. When I found excuses to avoid going into the field, staying with difficult experiences, and recording for ongoing analysis, Ortner's article became a useful way to become curious rather than despondent so that I could ultimately stay with the research. Because the ethnographer's experience is part of the data, ethnographic refusal also became part of the research both in developing my perspective as a research 
instrument and in identifying when this refusal was coming not from me personally but through others in the social environment. In other words, my experience of refusal was at times more internally driven by my personal reactions and at other times was more externally driven by experiencing the reactions and interactions of others. This article will focus on one problem of ethnographic refusal, which was driven by intensely personal and emotional dimensions. My study is on a family court child custody mediation program located in Milwaukee, Wisconsin. Background on mediation, family court applications, and current scholarship are next provided before describing the research study site specifics.

\section{Research study}

\section{Mediation as intervention}

Mediation as cultural practice in daily life has been common historically (Barrett, 2004; Roberts and Palmer, 2005). Mediation as professional practice first developed in the US during the 1960s and 1970s. The dominant model, also known as the "problem-solving model" has been globalized across a wide range of contexts in the US and abroad (Barrett, 2004; Coben, 2006). The basic steps are introductions, opening statements describing problems, identifying issues, exploring options, evaluating potential solutions, and the potential to reach settlement. In social work literature, the problem-solving mediation model is identified as potentially empowering intervention for family conflict given emphasis on supporting disputants as they identify issues, options for resolution, and then take responsibility for final outcomes (Kruk, 1997; Munro, 1997). Mediation proponents theorize that mediation empowers litigants in court processes by allowing the parties to negotiate directly, include issues that may not be legally relevant to the case, and provide a final agreement to the court (Kandel, 1995).

In US family courts, mediation as alternative dispute resolution (ADR) tool became part of the "velvet revolution" (Singer, 2009) as no-fault divorce laws swept in major changes of law and social norms in the 1970s and 1980s. While divorce had previously been a primarily legal determination of fault and property division, couples could now file if the marriage was "irretrievably broken" (Vlosky and Monrole, 2002). Rather than award child custody (major decision-making authority) or placement (child residence) based on fault finding, the legal standard became determination of the "best interests of the child" (Johnston, 2000). Social science research provided data for an evolving "good divorce" ideal in which parents could dissolve a marriage or non-legalized relationship and still co-parent amicably for the benefit of their children (Amato et al., 2011). Adversarial divorce lawyers were supplemented-and potentially replaced-with more therapeutically minded (and professionally trained) experts who could both identify placement schedules in the best interests of children and to help parents cooperate in co-parenting. While there are full time mediators in this field, most are lawyers or mental health professionals, such as social workers, who have added mediation as a specialization. Today, mediation is not only a service offered by most family courts (Singer reports a survey finding of $92 \%$ of family courts, p. 373 ) but has also become widely mandated (Singer, 2009) across most US states. Mediation as family court intervention is also found globally, with similar rationale provided through legal systems addressing divorce and non-marital parenting in Asia, Australia, Europe, Canada, and more recently introduced in the 2000s in Latin America and Africa (Boshier et al., 2011; Crook, 2012; Dingwall and Eekelar, 1988; Lundberg and Maloney, 2010; Maclean, 2010; Murayama, 2010; Wang, 2013). Cross national variations include whether the underlying purpose is marital conciliation (as found in Asia) or amicable separation (as common to English speaking countries), and whether mediation is offered within the court or contracted out to family service providers.

Empirical support for mediation in the US is almost entirely based on studies conducted in the 1980s and 1990s (Emery et al., 2005; Kelly, 2004; Saposnek, 2004). In family law, more substantial recent research and government sponsored reports have been conducted in England and Australia and New Zealand (e.g. Boshier et al., 2011; Maloney et al., 2013; Trinder and Kellet, 2007). Common questions addressed across this research 
include the benefit of mediation and modified mediation models of programs and practice. As a study within one county in the US, this study may inform international discussion not as representative of the entire variation of models and contexts but rather in providing case studies including the complex interaction of factors found as salient in scholarship and practice. Examples include mandatory mediation, court embedded processes, and high conflict couples (e.g. Salem, 2009). The overall research setting and design follows.

\section{Research setting: Milwaukee family court}

The Milwaukee County Family Court has a large and diverse caseload, serving an urban, rural, and suburban population. Of the 955,205 residents in 2012, 65.5\% were white, 27.2\% were Black or African American, $13.9 \%$ were Hispanic or Latino, and 3.7\% were Asian (US Census Bureau, 2013). Parents file in family court for divorce, restraining orders, child support orders or modification, and child custody and/or placement orders or modification. In Wisconsin, as in many other states, parents in dispute over child custody (legal decision making) and/or placement (physical residence) must attend mediation before continuing in the court process (Applegate and Beck, 2013). The mediation program is comparable to other programs across the country in the use of the mediation model as described in the literature review and in attempting to offer mediation as voluntary while upholding legal requirements. Mediation referrals may come through parent request, through family law attorneys, or by court order. In order to allow refusal within a mandated program, the mediation requirement is an evaluation session held at the courthouse. Mediated agreements typically become the final court order, and failure leads to appointment of an attorney as guardian ad litem (GAL) to investigate the best interests of the children and make custody and placement recommendations in a follow-up hearing.

\section{Research study design and data collection}

Most empirical study of mediation practice has focused on individual mediation sessions or individual mediation cases as the unit of analysis. This study continues this trend for comparative purposes. In addition, an ethnographic extended case study design was added to better contextualize mediation session meanings and outcomes (Burawoy, 1998). This means following cases beyond individual mediation sessions to mediation cases as a whole embedded within a process of court filings, hearings, and either final orders or case dismissal. This also means immersing myself within mediation program contexts while conducting informal interviews during these processes (as appropriate). In this study, contexts include a 40-hour mediator training commonly used to qualify for the court roster, mediation program annual trainings and monthly "roundtable" debriefings, courtbased procedures, mediation evaluation sessions, and mediation sessions. In addition, semi-structured interviews are conducted following mediation with parents and mediators. Parents are compensated US\$30 per semi-structured interview but otherwise research participants are not paid.

Preliminary data of context immersion and initial mediation observation were collected over three months in 2011. Field immersion then continued with a focus on extended case study data collection from May 2012 through the present. One court commissioner and family court judge in particular have acted as key informants. Mediation cases were collected as a convenience sample of 41 mediation cases, 60 mediated sessions typically 90 minutes to two hours in length, 28 parent interviews, and 16 mediator interviews. Twelve mediation cases include interviews with both parents. There was intentional sampling of mediators in that the five mediators observed during mediation sessions were each interviewed. Most mediation sessions, 27 parent interviews, and 11 mediator interviews are audio-recorded.

In terms of context immersion, I had developed rapport with mediators and court professionals running the court mediation improvement project as a research consultant. After creating a requested survey for the project, I began participation as a researcher. Data have been collected with IRB approval. 


\section{Initial ethnographic stance}

My initial ethnographic stance was that of a mediator with previous research and practice experience in other types of mediation cases. I had no background in family law or direct personal experience as a parent or spouse. My initial research goal was to update empirical literature, which included how effectively mediation lived up to stated empowerment claims. Professional questions of intervention efficacy were soon dissolved, however, within the high seas of emotional and interpersonal distress. Ethnographic refusal was experienced as a problem of not knowing how to avoid or perhaps surf the waves. At times I felt merely the witness of nonstop heartbreak, which seemed unseemly to record for publication. I took breaks, discharged my angst in a journal, and reduced recording to basic dictation of hearings and evaluation sessions coupled with audio recording of mediation sessions and more formal interviews. At best, my observation notes were elaborations on the impersonal court file data. Immediacy of data collection was also buffered by research assistants hired to observe evaluation sessions and mediations. However, this also prevented necessary change in ethnographic stance by restricting my ability to absorb emic perspectives. At one point, I realized I had to either drop the project or find a way to get unstuck. Overtime, I did not get over my reluctance as much as used it as data. A sketch of how context immersion brought refusal, and how refusal led to insight comes next.

\section{Going into context(s) and meeting refusal}

\section{Lost in emotion with no room for romance}

The Milwaukee County Courthouse is a huge, stone edifice with high ceilings that seem intended to tower above the mere mortals who seek or require greater authority over their affairs. Family court is on the top floor. Each morning, a deputy unlocks the door to let litigants inside, telling all "supporters" to wait in the hall. Inside consists of a large room with a clerk at one end who processes initial files and a clerk towards the other end who checks in litigants. Both work behind clear plastic walls that suggest a need for protection from the public. The check-in clerk has a prominent sign telling people to wait behind the thick red line painted on the floor until they are called. Not far from the check-in clerk is a small seating area for armed deputies available in case people get out of hand while waiting for cases. There was a time, for example, when a person filing for a restraining order was followed in by the person she was planning to restrain (who wanted to change her mind).

The waiting area has a white tiled floor and white walls that are generally bare except for two bulletin boards with a combination of court processing information and brochures from local social services. A large sign entitled, THIS IS A COURTROOM reminds people of middle class manners, such as "No Eating or Drinking" and "Remain quiet while waiting." Dated magazines lie stacked in a large windowsill of one of two windows. People can either wait in plastic chairs set up in four large rows or seated at one of five small square tables. The tables provide a space for litigants to meet with attorneys and GALs as well as potentially negotiate with opposing parties while waiting for a hearing.

Off to the sides of the waiting room are court staff offices and two hallways with court commissioner hearing rooms. Mediation evaluation sessions are held here. Asked to describe the court experience of the mediation evaluation session, one female parent said she felt, "horrible ... like scum of the earth, placed into a room that was cold-non decorative-looked like I was standing in line for food stamps." A male parent described "707," (the room number for family court) as particularly bad for men, "the worst place you can go. It's kind of like ahell. You see these guys, just like this with their heads down (demonstrates as talks) just knowing they're going to get-that we're screwed."

Going into this research, I knew the straightforward goal of mediation to put control from the court back into the hands of parents such that a court order can be written and entered into the case file. This was the explanation I heard countless times from court commissioners and judges as they referred parents and provided 
by mediators in the evaluation and mediation sessions. Yet, this basic explanation did not fit with subjective dynamics and emotional responses that potentially derailed case resolution. I still remember sitting within inches of a divorcing couple with two young children at home. The father had an attorney but the mother did not because, "that would make it real." The father's attorney explained she had filed the motion that brought them to court because the case wasn't moving forward. The judge set a dismissal date and said he would not force anyone's hand. He told them, "I don't care if you divorce" but his tone suggested otherwise. The father looked a little dazed, the mother sat stiffly in her chair. As one child support officer explained, "parents in family court can only hear what you get from hearing the sea in a seashell" - and illustrated with a whooshing sound.

While this couple seemed paralyzed, others were far more animated and even enraged. In some cases, they had been in court many times over many years; one mediator calls them "frequent flyers." Most parents could stay under control during court hearings and mediation sessions. As they remarked during informal conversation and interviews, however, there was often a lot more chaos outside of formalized meetings and a potentially uglier side, such as desire to cause harm. One mediation case started smoothly. In the first session, the mother seemed apologetic about divorce, and in the second, the parents gently chided the mediator for posting a list of ground rules that began with, "treat each other with respect and \& courtesy" because it did not seem necessary. Yet, mediation was followed by a domestic violence incident and court restraining order. The mother did not return my call but the father wanted to talk. "I didn't do it," he told me, "but you probably get that all the time." He brought a letter from his wife to read during the interview. As follows in the transcript,

"This is an apology letter. It's not really an apology letter, but ..."

“-Apology slash explanation?"

"No, apology slash, 'It's your fault.'”

The domestic violence case was later dismissed. Over a year later, the mother told me that it had only "got me $\$ 2600$ in attorney fees" and no help with house or kids for the duration of the restraining order. He later moved back in for three months to attempt reconciliation but they eventually divorced. As in other mediation and court cases, the basic truths of whether, when and how of conflict and relationship dynamics continued to change for each party and as an often incoherent story of what was really happening. For example, the couple just mentioned gave different stories of the domestic violence incident, the mother saying they would never agree on whether she was at fault for calling the police or he was at fault for pushing her against a wall and holding her to prevent leaving. Even seemingly neutral facts may be disputed; in one mediation, the parents provided different grades as evidence that the child was and was not doing well in school. The challenge of parent volatility and emotions is a frequent topic among professionals as they talk about cases. One mediator who had been a longtime public defender said that she had thought family cases would be "a walk in the park." Instead, she finds a "level of irrationality" that is different from criminal cases in that, "I have had people set other people on fire and not have it be this personal."

\section{Politically personal}

In the early stages of research, there were many ways to get caught up in the politics of the personal. In interviewing each parent following mediation, it was easy to engage sympathetically with each only to be left with incompatible and sometimes hostile views of the other and of the situation. One parent warned me of how charming and manipulative the other can be, which left me wondering if I had missed that dynamic from the interview. Had I been duped by the parent-if so, which one? A few parents used research participation as part of battling the other parent; one used the scheduling of an interview with me to dismiss the other parent's effort to talk following a hearing, while another asked me who did better in mediation. 
Local politics even became part of how to organize the data. In trying to fully appreciate multiple perspectives, I had options on how to privilege perspectives: Should I use case file numbers, which privileges the court filing system as the reasonable, sense-making actor in this messy social process? Start with court or mediation program process, which privileges commissioner and mediator perspectives respectively? Or, let the parents tell me how this all started, which inevitably would reach into histories and contexts from when court was never part of the plan, much less mediation. It seemed impossible to not take sides. Then again, it was hard at times to discern what sides were there. For example, in response to my suggestion that courts have an ideal of how parents should be and the way things should be, a judge retorted that, "There are no shoulds," because what the courts require is based on a 500-year-old system that changes as the times change, coupled with legislative battles.

\section{Dissolving research topic}

The question of empowerment in professional mediation literature contains an implicit assumption that intervention precedes context in order to compare mediation in ideal form to how it holds up in real live context. In trying to effectively show up before the mediation-by starting with context and then observing mediation as an interactive part of a larger process, mediation as intervention model was hard to find. Instead, mediation in ideal form was merely that-an ideal, an abstraction, something that was more likely used to "sell" mediation to parents than to describe lived experience. It was also used by newer mediators to describe what they do and to direct their initial efforts before parents potentially derailed the process by failing to act as independent rational actors taking on the role of "mom" or "dad." As my research topic seemed to dissolve, I thought of my quandaries as that of ethnographic refusal; the problem is not that there are no data but that the data cannot be recognized and analyzed as if following the forms and patterns presented in professional model standards. There is something more then that requires articulation for a more complete description. The question was how to work through refusal to re-discover the data, dissolving the assumptions with which I entered the field and allowing patterns to emerge from the field data for analysis.

\section{Working through refusal and refining my stance}

At first, refusal was merely my term for feeling overwhelmed and reluctant to return to the field or write up field notes upon return. I addressed this refusal as an occupational hazard of research on sensitive subjects with vulnerable participants (see Padgett, 1998). As in social work practice, I needed to learn to surf the emotional intensities without becoming overwhelmed or seeming to choose sides. Emotionally, I used my journal to sort out personal reactions and compared my reactivity to those of my assistants so as to lessen personal bias and projections. Mediators use similar debriefing methods (Lundberg and Maloney, 2010).

My second approach was to consider this emotional intensity as data. Personal reactions and emotional intensity became a point of inquiry for observation and direct questions posed to interlocutors. For example, one new mediator was disappointed by lack of intensity following experience counseling combat veteran families. Another explained, "you have to be like a turtle and let the water wash off your back," perhaps mixing metaphors as a way to respond to the both felt need to withdraw and the more acceptably professional stance of simply not letting others get to you. I tested out the metaphor of family court as attempted navigation in emotional high seas by explaining to one legal professional that the law seemed to be used by legal professionals as a sort of life raft to avoid getting in too deep. She added sharks to the metaphor. As recorded in my notes, "try not to swim with the sharks, stay on the raft ... emotions, want to be heard." At times, professionals also strove to feel heard as some parents argued with them freely.

The passion with which legal professionals and mediators sometimes responded to parents became another source of inquiry. Overtime, I realized that the personal was not limited to my responses or to parents. In particular, legal and mediator professionals sometimes spoke personally when engaging parents in court and/or 
mediation, such as advising based on experience as a parent, spouse, or divorced partner. More than one professional was not disinterested in outcomes but rather stated that concern for children drove their interest in mediation and in particular dispute outcomes. In working this out through analytic memos, it seems that the family court goal of rational decision-making was often thwarted by the personal and emotional interests of most participants. Court hearings and mediation sessions were a continual struggle for the rational to triumph over the personal and emotional. Yet, this sometimes brought even more rage from parents. Recognizing this, legal professionals hope mediation offers a pressure valve for emotions not allowed in court, while mediators debate how much to allow the personal into mediation as "elephants in the room" that may be a necessary component or an inevitable derailment to mediation success.

In addition to examining the personal as a source of distress (and refusal), I examined this discomfort for insight on local politics and culture. This brings in Burawoy's "second dialogue" in reflexive research (p. 5). The intense emotions of family court are largely attributed to human frailty, selfishness, and the dysfunction of parentssometimes by the parents themselves. In addition, this emotional intensity triggers that of professionals and is frequently met with rational defense (again, by parents as well as professionals). However, there are deeper sources of conflict that are fueling this intense personal experience. One is how family law has not kept pace with why people marry, have children, or separate; what were economic considerations and problems of property division are now rooted in emotional goals (Coontz, 2006). When choice of partnership and children are emotionally more than materially based, disputes over children reasonably bring intense emotional distress. Thus, staying with the emotional and personal as a point of inquiry continues to thicken ongoing insight for further analysis.

\section{Revised ethnographic stance}

Ortner locates the problem of ethnographic refusal in romanticizing and politically sanitizing data through analysis. Was I holding on to romantic and apolitical representations of research subjects and local realities? I find there is a romantic dimension to professional models that characterize participants in idealized roles rather than in a fuller and more messy humanity (except that which can be managed or transformed by the professional). In mediation, mediators are neutral facilitators who can ultimately engage disputants simply as parents focused on the needs of their children. Only parents have emotions which are limited to initial venting and loving care towards children. Mediation experts have debated the merits of this narrow construction, and how to modify for more realistic representation of practice (e.g. Dingwall, 2010; Gibson et al., 1996).

Practitioners expand model flexibility through advanced trainings and model modifications (e.g. Bush and Folger, 2005). This romance is therefore not news to mediation scholars and professionals, although more typically addressed as a problem of mediation ideology (see Salem, 2009).

In addition to the romancing of intervention work in professional discourse, there is of course the romance of romance and emotional fulfillment as the basis of family. A reminder came at the courthouse the day that dozens of gay couples joyously married following a state Supreme Court decision overturning a state ban on gay marriage. People want in on the family ideal, so they are understandably devastated when it is lost. Ideological constructs of family as entirely positive and affirming leaves much room for refusals to address disappointment let alone uglier truths such as domestic violence. Refusal in this sense is an inevitable and integral part of my research. It also provides entry to the second and third dialogues of reflexive research. I have expanded my literature review to social histories, feminist legal scholarship, and sociological study of the family, which traces ideals and social realities of family, family law, divorce, and parenting over generations (e.g. Cherlin, 2009, Coontz, 2006). This scholarship is surprisingly absent from family mediation literature, and a rich source of theory on the family ideal in relation to family law and social realities (e.g. Fineman, 1991; Lazarus-Black, 2007). 
In terms of political sanitizing, the ways in which parents occasionally attempted to draw me into personal politics is now an expected occupational hazard of close engagements. A more surprising politics has been social pressure against acknowledging strong emotion and personalized politics as part of intervention rather than as dysfunctional behavior to ignore, manage, or condemn as unreasonable. Of course, the boundary between acceptable and unacceptable emotion is not fixed, and where to draw lines is another dimension to the politics of the personal.

As in questioning romance, intragroup politics as a research question also leads to searching deeper for underlying causes. Why did it seem intensely political to choose how to organize my data? Why did the court, mediator, and parent perspectives seem at times incommensurable and contestable? One reason is that there is room for conflict given ambiguity in the role of the state in private family lives. The state has a responsibility to intervene and protect vulnerable people, such as children, but family court is for parents who are also responsible for their own children. Parents have the right to determine how to co-parent, and are presumed to be equally "good" parents. When parents file against each other in court, what role should the court play in determining the best outcome? What role is realistic given scarce resources? As the judge said, there are no "shoulds." In this context, frequent flyer parents can be quite savvy in how to use ambiguities of law and lack of enforcement to continue battles through court. And the necessity of co-parenting as a weekly if not daily activity over the first 18 years of each child's life allows much room for conflict despite court orders and mediated agreements. As a court file clerk said, "family cases never die."

Finally, in application of theory, Mary Douglas's work on rituals of purity and danger has been useful (Douglas, 1966). Declarations such as "I don't care" when delivered with passion suggest a more complex relationship between the emotional and rational than a binary opposition. In Douglas's work on religious ritual, she found a common pattern of using taboo as a means of ordering social life. Her famous phrase is, "Dirt is matter out of place" (Douglas, 1966:2). In other words, the problem of dirt is only a problem once this matter is perceived as a cause of disorder. In this research, strong emotions and parent interests beyond their children's welfare become "dirt" to manage if not remove. Parents unwilling or unable to co-parent implicitly challenge the family functioning ideal, which can be realized by putting them back in place through court ordered sharing of custody decision making or placement schedules. This work effectively re-creates the nuclear family without an underlying conjugal bond as ex-partners are told to put aside their differences and cooperate in parenting (with perhaps more coordination and shared responsibility than when they were a couple). Mediation is used to address parental messes that prevent this goal, with a warning that they will be subjected to legal investigation and court orders if unable to reasonably cooperate. Mediation as part of court process then becomes a ritual of purity and danger, in which the purity (or ideal) of rational decision-making in the best interests of children by biologically (or at least legally) related parents is constructed through attention to danger seemingly posed by strong emotions, personal interests, and adversarial parent dynamics. Parents who cannot or will not comply are treated as failures. For example, a parent lost placement time after the GAL identified her as "random" and therefore less capable of parenting. However, this is not simply a rational court against emotional parents. Child custody disputes are filed by parents who use rational arguments to construct themselves as an ideal parent to ensure success.

Coming back to Ortner's complaint of thinning out complex dynamics of domination and resistance, professional intervention work itself can be interpreted as a kind of thinning. That is, people bring disordered and complicated lives to court, which professionals try to order. My working hypothesis is that family court mediation as intervention is a form of thinning in which complex and emotionally intense lives are reduced to seemingly more manageable frameworks and best practices. Success is experienced when this form of thinning is welcomed, such as when providing relief to discomfort from complexity or dysfunction, and when parents want to stay in contact and to co-parent. Parents are also obviously more satisfied when final court orders 
match their expectations and intentions. Given how no model can fully represent the full variation of social reality (Mitchell, 2002), however, failure is always an option for one or more people. This means that empowerment and coercion experienced by parents through the court and mediation processes are in part contingent on situational factors and parent perceptions beyond professional control. And the tension of mediated court cases can come in part from competitive thinning, as parents and professionals argue for different solutions in navigating high seas of emotion and relationship dysfunction against the vague legal prescription in Wis. Stats. ch. 767, § 4.a.2. that placement should "maximize time with each parent." The story is then not a simple one of court ritual purity as much as a politics of taboo (Wis. Stats. Updated 2011-2012).

\section{Conclusion}

Ethnographic research methods and direct social work practice both use personal engagement to earn trust, develop rapport, and "go deep" into understanding what another is experiencing-as interlocutor or as client (Bloch, 2012). In this process are dangers of going too far as well as not going far enough to gain understanding. This boundary between too much and not enough is topic in qualitative social work research methods (e.g. Padgett, 2008; Valentine, 2007) and reflections on the ethnographic self in the field (e.g Collins and Gallinat, 2010). My concern in this study was a problem of pulling back at risk of losing valuable insight. Using Ortner's term, ethnographic refusal is a failure of nerve, perhaps in the guise of ethical or professional detachment. The result is thinning of understanding and insight, as well as denying the full humanity of individuals and the complex cultural context of a bigger picture. The intimacies of qualitative field research allow people to speak and act freely, almost as if there were no research instrument (because that instrument is a person folded into the social environment). This brings an occupational hazard of learning unflattering and politically sensitive data while feeling drawn to take sides. Staying with these dilemmas provides a means to refine one's ethnographic stance. This can also lead to analytic insight to thicken understanding of the larger social and cultural contexts in which individual problems are identified for intervention. Refusal can thus be highly productive as method rather than a problem to solve or a reason to give up.

\section{Funding}

Funding was provided through the Marquette University Regular Research Grant (RRG) and Summer Faculty Fellowship (SFF) programs as well as the Center for Peacemaking's Rynne Research Fellowship.

\section{Acknowledgments}

This research would not be possible without research permission from the Milwaukee Family Court as well as the permission, time, patience, and candor of research participants. As this article developed, several colleagues provided critical feedback from academic, legal, and ADR practitioner perspectives: Shannon Corallo, David Crampton, Robert Dingwall, Rebecca Gandy, Kevin Gibson, Sandra Grady, Gale Miller, and Andrea Schneider. I would like to thank all of them, as well as the anonymous reviewers, for their time, interest, and important insights for improving the manuscript. Responsibility for final content rests with me.

\section{References}

Amato, P, Kane, J, Spencer, J (2011) Reconsidering the 'good divorce'. Family Relations 60: 511-524.

Applegate, A, Beck, C (2013) Self-represented parties in mediation: Fifty years later it remains the elephant in the room. Family Court Review 51(1): 87-103.

Barrett, J (2004) A History of Alternative Dispute Resolution, San Francisco, CA: Jossey-Bass.

Behar, R (1996) The Vulnerable Observer, Boston: Beacon Press.

Bernard, HR (2002) Research Methods in Anthropology: Qualitative and Quantitative Approaches, Thousand Oaks, CA: SAGE. 
Block E (2012) That's what I see: Enhancing AIDS intervention research through deep ethnography. Qualitative Social Work 11(4): 379-394.

Börjesson, U (2014) From shadow to person: Exploring roles in participant observations in an eldercare context. Qualitative Social Work 13(3): 406-420.

Boshier Hon, P, Taylor, N, Seymour, F (2011) Early intervention in New Zealand family court cases. Family Court Review 49(4): 818-830.

Burawoy, M (1998) The extended case method. Sociological Theory 16(1): 4-33.

Burawoy, M (2003) Revisits: Outline of a theory of reflexive ethnography. American Sociological Review 68(5): 645-679.

Bush, R, Folger, J (2005) The Promise of Mediation, San Francisco: Jossey Bass.

Cherlin, AJ (2009) The Marriage-Go-Round, New York: Knopf.

Clifford, J, Marcus, GE (1986) Writing Culture, Berkeley: University of California Press.

Coben, JR (2006) Intentional conversations about the globalization of ADR. Hamline Journal of Public Law \& Policy 27: 217-227.

Collins, P, Gallinat, A (2010) The Ethnographic Self as Resource, New York: Berghan.

Coontz S (2006) Marriage, a History. New York: Penguin.

Crook R (2012) Alternative dispute resolution and the Magistrate's Courts in Ghana. Working Paper 25. Africa Power and Politics Programme London: Overseas Development Institute. Available at: http://www.institutions-africa.org/filestream/20120703-alternative-dispute-resolution-and-themagistrate-s-courts-in-ghana (accessed 13 October 2014).

Davies, C (1999) Reflexive Ethnography, London: Routledge.

Dingwall, R (2010) Divorce mediation: Should we change our mind? Journal of Social Welfare and Law 32(2): 107-117.

Dingwall, R, Eekelaar, J (1988) Divorce Mediation and the Legal Process: British Practice and International Experience, Oxford: Oxford University Press.

Douglas M (1966) Purity and Danger. New York: Praeger.

Duneier, M (1999) Sidewalk, New York: Farrar, Straus and Giroux.

Emery, R, Sbarra, D, Grover, T (2005) Divorce mediation: Research and reflections. Family Court Review 43(1): 22-37.

Fetterman, D (2009) Ethnography. In: Bickman, L, Rog, D (eds) The SAGE Handbook of Applied Social Research Methods, 2nd ed. Thousand Oaks, CA: SAGE, pp. 543-588.

Fineman M (1991) The Illusion of Equality. Chicago: University of Chicago Press.

Flick, U (2014) An Introduction to Qualitative Research, 5th ed. Los Angeles: SAGE.

Floersch, J, Longhofer, JL, Nordquest Schwallie, M (2013) Ethnography. In: Gray, M, Webb, S (eds) Social Work Theories and Methods, Los Angeles: SAGE, pp. 195-205.

Floersch, J, Longhofer, J, Suskewicz, J (2014) The use of ethnography in social work research. Qualitative Social Work 13(1): 3-7.

Geertz, C (1973) The Interpretation of Cultures, New York: Basic Books.

Gibson, K, Thompson, L, Bazerman, MH (1996) Shortcomings of neutrality in mediation: Solutions based on rationality. Negotiation Journal 12: 69-80.

Goffman, E (1988) On fieldwork. Journal of Contemporary Ethnography 18(2): 123-132.

Haight, W, Kayama, M, Korang-Okrah, R (2014) Ethnography in social work practice and policy. Qualitative Social Work 13(1): 127-143.

Iversen, R, Armstrong, A (2007) Parents' work, depressive symptoms, children, and family economic mobility: What can ethnography tell us? Families in Society 88(3): 339-350.

Johnston, J (2000) Building multidisciplinary professional partnerships with the court on behalf of high-conflict divorcing families and their children: Who needs that kind of help? ULAR Review 22: 453-479.

Kandel, R (1995) 'Developmental Appropriateness' as law in California child custody mediation: Towards a jurisprudence of persuasion. Journal of Legal Pluralism 35: 75-118. 
Kelly, J (2004) Family mediation research: Is there empirical support for the field? Conflict Resolution Quarterly 22(1-2): 3-35.

Kruk, E (1997) Mediation and Conflict Resolution in Social Work and Human Services, Chicago: Nelson-Hall. Lazarus-Black (2007) Everyday Harm, Chicago: University of Illinois Press.

Lundberg, D, Maloney, L (2010) Being in the room: Family dispute practitioners' experience of high conflict family dispute resolution. Journal of Family Studies 16(3): 209-223.

Maclean, M (2010) Family mediation: Alternative or additional dispute resolution? Journal of Social Welfare \& Family Law 32(2): 105-106.

Maloney, L, Weston, R, Hayes, A (2013) Key social issues in the development of Australian family law:

Research and its impact on policy and practice. Journal of Family Studies 19(2): 110-138.

Mitchell, T (2002) Rule of Experts, Berkeley, CA: The University of CA Press.

Mosse, D (2005) Cultivating Development, London: Pluto Press.

Mosse, D (2011) Introduction. In: Mosse, D (ed.) Adventures in Aidland, New York: Berghan Books, pp. 1-39.

Munro, D (1997) Using unconditionally constructive mediation to resolve family-system disputes related to personal with disabilities. Families in Society: The Journal of Contemporary Social Services 78(6): 609616.

Murayama, M (2010) The origins and development of family conciliation in Japan: A political aspect. Journal of Social Welfare \& Family Law 32(2): 143-153.

Ortner, SB (1995) Resistance and the problem of ethnographic refusal. Comparative Studies in Society and History 37(1): 173-193.

Padgett, D (1998) Qualitative Methods in Social Work Research, London: SAGE.

Padgett, D (2008) Qualitative Methods in Social Work Research, 2nd ed. London: SAGE.

Pearson, C, Bourgois, P (1995) Hope to die a dope fiend. Cultural Anthropology 19(4): 587-593.

Roberts, S, Palmer, M (2005) Dispute Processes, Cambridge: Cambridge University Press.

Rosaldo, R (1993) Culture and Truth, Boston: Beacon Press.

Salem, $\mathrm{P}$ (2009) The emergence of triage in family court services: The beginning of the end for mandatory mediation? Family Court Review 47(3): 371-388.

Saposnek, D (2004) Commentary: The future of the history of family mediation research. Conflict Resolution Quarterly 22(1-2): 37-53.

Schensul, J, LeCompte, M (2013) Essential Ethnographic Methods, Walnut Creek CA: Altamira Press.

Singer, J (2009) Dispute resolution and the postdivorce family: Implications of a paradigm shift. Family Court Review 47(3): 363-370.

Trinder $L$ and Kellett J (2007) The longer-term outcomes of in-court conciliation. Report, Ministry of Justice Research Series 15/07. Available

at: http://socialsciences.exeter.ac.uk/media/universityofexeter/schoolofhumanitiesandsocialsciences

/law/research/familyregulationandsociety/The Longer-Term Outcomes of In-

Court Conciliation.pdf (accessed 13 October 2014).

US Census Bureau (2013) State and county quick facts. Available

at: http://quickfacts.census.gov/qfd/states/55/55079.html (accessed 13 October 2014).

Valentine, C (2007) Methodological reflections: Attending and tending to the role of the researcher in the construction of bereavement narratives. Qualitative Social Work 6(2): 159-176.

Vlosky, D, Monroe, P (2002) The effective dates of no-fault divorce laws in the 50 states. Family Relations 51(4): 317-324.

Wang, J (2013) To divorce or not to divorce: A critical discourse analysis of court-ordered divorce mediation in China. Journal of Law, Policy, and the Family 27(1): 74-96.

Wesch, M (2007) A witch hunt in New Guinea: Anthropology on trial. Anthropology and Humanism 32(1): 417.

Wis. Stats. Updated 2011-2012. Chapter 767.001. Published and certified under s. 35.18. Available at: http://docs.legis.wisconsin.gov/statutes/statutes/767.pdf (accessed 13 October 2014). 
